\title{
POTASSIUM FERTILIZATION FOR PINEAPPLE: EFFECTS ON SOIL CHEMICAL PROPERTIES AND PLANT NUTRITION ${ }^{1}$
}

\author{
LUIZ ANTONIO JUNQUEIRA TEIXEIRA², JOSÉ ANTONIO QUAGGIO³, \\ HEITOR CANTARELLA ${ }^{4}$, ESTÊVÃO VICARI MELLIS ${ }^{5}$
}

ABSTRACT - A field experiment was carried out on an Ultisol located at the city of Agudos (22 30 's; $49^{\circ} 03^{\prime}$ 'W), in the state of São Paulo, Brazil, in order to determine the effects of rates and sources of potassium fertilizer on nutritional status of 'Smooth Cayenne' pineapple and on some soil chemical properties. The experiment was a complete factorial design with four rates $\left(0,175,350\right.$, and $700 \mathrm{~kg} \mathrm{ha}^{-1}$ of $\left.\mathrm{K}_{2} \mathrm{O}\right)$ and three combinations of $\mathrm{K}$ sources $\left(100 \% \mathrm{KCl}, 100 \% \mathrm{~K}_{2} \mathrm{SO}_{4}\right.$ and $\left.40 \% \mathrm{~K}_{2} \mathrm{SO}_{4}+60 \% \mathrm{KCl}\right)$. Soil samples were taken from the depths $0-20 \mathrm{~cm}, 20-40 \mathrm{~cm}$ and $40-60 \mathrm{~cm}$ at planting and 14 months after. Nutritional status of pineapple plants was assessed by means of tissue analysis. Soil K availability increased with application of $\mathrm{K}$ fertilizer, regardless of $\mathrm{K}$ sources. Soil chlorine and $\mathrm{Cl}$ concentration in pineapple leaves increased with application of $\mathrm{KCl}$ or $\mathrm{K}_{2} \mathrm{SO}_{4}+\mathrm{KCl}$. Plant uptake of potassium was shaped by soil $\mathrm{K}$ availability and by the application rates of $\mathrm{K}$ fertilizer, independently of $\mathrm{K}$ sources.

Index terms: Plant analysis, soil analysis, potassium chloride, potassium sulphate, Ananas comosus / K.

\section{ADUBAÇÃO POTÁSSICA EM ABACAXIZEIRO: EFEITOS NO SOLO E NA NUTRIÇÃO DAS PLANTAS}

RESUMO - Foi realizado um experimento de campo num Argissolo Vermelho-Amarelo, em Agudos-SP $\left(22^{\circ} 30^{\prime} \mathrm{S} ; 4^{\circ} 03^{\prime} \mathrm{W}\right)$, com o objetivo de determinar os efeitos de fontes e doses de fertilizante potássico no estado nutricional de abacaxi 'Smooth Cayenne' e em alguns atributos químicos do solo. Empregou-se um arranjo fatorial com quatro doses $\left(0 ; 175 ; 350\right.$ e $\left.700 \mathrm{~kg} \mathrm{ha}^{-1} \mathrm{de}_{2} \mathrm{O}\right)$ e três combinações de fontes $(100 \%$ $\mathrm{KCl}, 100 \% \mathrm{~K}_{2} \mathrm{SO}_{4}$ e $\left.40 \% \mathrm{~K}_{2} \mathrm{SO}_{4}+60 \% \mathrm{KCl}\right)$. A amostragem de solo foi realizada nas camadas de 0 a $20 \mathrm{~cm}$, 20 a $40 \mathrm{~cm}$ e de 40 a $60 \mathrm{~cm}$ na época do plantio e 14 meses depois. O estado nutricional dos abacaxizeiros foi avaliado por meio de análise foliar. A disponibilidade de $\mathrm{K}$ no solo aumentou em função das doses, independentemente da fonte empregada. A concentração de cloro no solo e seu teor nas folhas de abacaxizeiro cresceram com a aplicação de $\mathrm{KCl}$ e de $\mathrm{K}_{2} \mathrm{SO}_{4}+\mathrm{KCl}$. A absorção de potássio pelo abacaxizeiro apresentou correlação significativa com as doses de $\mathrm{K}$ aplicadas, independentemente da fonte.

Termos para indexação: Análise de plantas / análise de solo / cloreto de potássio / sulfato de potássio / Ananas comosus / K.

${ }^{1}$ (Trabalho 141-10). Recebido em: 01-06-2010. Aceito para pubilcação em: 07-01-2011.

${ }^{2}$ Researcher. Centro de Solos e Recursos Ambientais do Instituto Agronômico (IAC). PO Box 28, 13012-970, Campinas-SP, Brazil. teixeira@iac.sp.gov.br

${ }^{3}$ Researcher. Centro de Solos e Recursos Ambientais do Instituto Agronômico (IAC). quaggio@iac.sp.gov.br ${ }^{4}$ Researcher. Centro de Solos e Recursos Ambientais do Instituto Agronômico (IAC). cantarella@iac.sp.gov.br ${ }^{5}$ Researcher. Centro de Solos e Recursos Ambientais do Instituto Agronômico (IAC). evmellis@iac.sp.gov.br 


\section{INTRODUCTION}

Potassium is the foremost nutrient required for pineapple crop and the lack of this nutrient reduces plant growth, fruit yield and affects negatively fruit quality as pointed out by Lacoeuilhe (1978, 1984) and Spironello et al. (2004). Therefore, potassium fertilization plays an important role to pineapple yield, but high rates of potassium chloride, the most common and cheapest source of this nutrient, can negatively affect fruit size and some internal fruit characteristics, as compared with potassium sulphate (LACOEUILHE, 1978).

The choice of an appropriate source of potassium may be as important as determining the correct rate of $\mathrm{K}$ fertilizer for some crops (ZEHLER et al., 1986). Potassium chloride is generally the cheapest source of $\mathrm{K}$, but the more expensive sources as sulphate and potassium nitrate provide other nutrients and have some advantages (HEPTON, 2003). According to Kleinhenz (1999), $\mathrm{K}_{2} \mathrm{SO}_{4}$ has advantages over $\mathrm{KCl}$ because it carries two major plant nutrients, has a lower salt index, is preferable for chloride-sensitive crops, and improves quality of many crops. Kleinhenz (1999) also mentioned that in the soil, chloride is more vulnerable to be leached than the sulphate, and in a similar manner, potassium $\mathrm{KCl}$-fertilizer is more readily leached than in $\mathrm{K}_{2} \mathrm{SO}_{4}$-fertilizer.

Despite the importance of potassium on pineapple nutrition, there is a lack of information about the effects of $\mathrm{K}$ fertilizer sources on soil properties and on pineapple nutrition in Brazilian plantations. The objective of the present study was to assess the effects of rates and sources of potassium fertilizer on nutritional status of pineapple plants and on some soil chemical properties.

\section{MATERIAL AND METHODS}

The field experiment was located in Agudos ( $\left.22^{\circ} 30^{\prime} \mathrm{S} ; 49^{\circ} 03^{\prime} \mathrm{W}\right)$, Brazil, in a low fertility Ultisol. The soil $(0$ to $20 \mathrm{~cm})$ chemical characteristics before experiment placement (no lime applied) were: organic matter $=17 \mathrm{~g} \mathrm{dm}^{-3}, \mathrm{P}_{\text {resin }}=6 \mathrm{mg} \mathrm{dm}^{-3}, \mathrm{pH}$ in $0,01 \mathrm{~mol} \mathrm{~L}^{-1} \mathrm{CaCl}_{2}$ solution $=4.1$, exchangeable $\mathrm{K}$, $\mathrm{Ca}$, and $\mathrm{Mg}=0.7,3$, and $2 \mathrm{mmol}_{\mathrm{c}} \mathrm{dm}^{-3}$, respectively, $(\mathrm{H}+\mathrm{Al})=38 \mathrm{mmol}_{\mathrm{c}} \mathrm{dm}^{-3}$ and soil base saturation $=$ $13 \%$, measured according to the methods proposed by Raij et al. (2001). Three months before planting, the soil was limed. Lime requirement was calculated to increase the soil base saturation to $50 \%$ of the $\mathrm{CEC}$ at $\mathrm{pH} 7.0$ according to Spironello and Furlani
(1997). The climate was classified as Cwa-Köppen with dry winter.

The experiment was carried out inside a commercial plantation established in June, 2003. The plots were composed of three double rows $(0.5 \mathrm{~m}$ by $1.15 \mathrm{~m}) 8 \mathrm{~m}$ long $\left(39.6 \mathrm{~m}^{2}\right)$. Seven meters (approximately 35 plants) of central double row was considered for sampling. The plant spacing within the rows was $0.4 \mathrm{~m}$, resulting in a plant population of about 34,600 plants ha ${ }^{-1}$. Selected slips of the 'Smooth Cayenne' variety previously treated with fungicides and pesticides were used. .

It was applied a randomized blocks design, with four replications, using a factorial design $(4 \times 3)$, consisted of four rates $\left(0,175,350\right.$, and $700 \mathrm{~kg} \mathrm{ha}^{-1}$ of $\left.\mathrm{K}_{2} \mathrm{O}\right)$ and three combinations of $\mathrm{K}$ sources $(100 \%$ $\mathrm{KCl}, 100 \% \mathrm{~K}_{2} \mathrm{SO}_{4}$ and a mixture of $40 \% \mathrm{~K}_{2} \mathrm{SO}_{4}+60 \%$ $\mathrm{KCl}$ ). In the combined treatment, $\mathrm{K}_{2} \mathrm{SO}_{4}$ was applied in the first two dressings and $\mathrm{KCl}$ in the last two.

Phosphorus was totally applied 30 days after planting at the rate of $80 \mathrm{~kg} \mathrm{ha}^{-1}$ of $\mathrm{P}_{2} \mathrm{O}_{5}$ as single superphosphate (SSP) containing $18 \%$ of $\mathrm{P}_{2} \mathrm{O}_{5}$ and $10 \%$ of S. Nitrogen was applied at the rate of 600 $\mathrm{kg} \mathrm{ha}^{-1}$ of $\mathrm{N}$, as ammonium nitrate together with the potassium treatments. Fertilizers were surface applied, close to the plant base, on an area of maximum root activity, according to the following application schedule: $10 \%, 30 \%, 30 \%$, and $30 \%$ of the total rate, respectively $1,5,7$, and 9 months after planting. These optimal N, P, and $\mathrm{K}$ rates and fertilizers splitting schedule were determined in recent trials conducted with pineapple in the same region by Spironello et al. (2004) and Teixeira et al. (2002).

At the beginning of flower emission (September, 2004), leaf samples were taken to determine total of nutrient concentrations. The tissue sample comprised whole D-leaves (last fully developed leaf, often the longest leaf) collected from each plot (LACOEUILHE, 1984; CUNHA and CABRAL, 1999). Samples of plant tissue were analyzed according to Bataglia et al. (1983). Composite soil samples, each one with 8 subsamples, were taken from each depth $(0-20 \mathrm{~cm}, 20-40 \mathrm{~cm}$ and $40-60 \mathrm{~cm})$ from every replication of the treatments in November 2004. Soil analyses were processed according to the methods described in Raij et al. (2001). Chlorine extraction (plant tissue and soil) for chemical analysis were done by shaking with water and $\mathrm{Cl}$ was measures with an ion-selective electrode (RAYMENT AND HIGGINSON, 1992).

The effects of treatments were evaluated using analysis of variance (ANOVA). Differences among sources of $\mathrm{K}$ were assessed with Tukey multiple range test $(\mathrm{p}<0.05)$ when the effects of sources 
were statistically significant ( $p<0.05$ for the $F$ test in ANOVA). For the variables significantly affected by rates of $\mathrm{K}$, the quantitative effects of rates were determined adjusting regression equations. Only models (equations) statistically significant $(\mathrm{p}<0.05)$ were presented. When the interactions between rates and sources were significant, the equations for rates were established for each source.

\section{RESULTS AND DISCUSSION}

\section{Soil}

Among some chemical characteristics showed in Table 1, only soil $\mathrm{S}_{-} \mathrm{SO}_{4}$ and $\mathrm{Cl}$ contents were affected by sources of potassium. In general, fertilization with $\mathrm{K}_{2} \mathrm{SO}_{4}$ increased soil S-SO $\mathrm{SO}_{4}$ in comparison with $\mathrm{KCl}$ and soil $\mathrm{Cl}$ content was higher with $\mathrm{KCl}$ application.

The effects of $\mathrm{K}$ rates on the soil exchangeable $\mathrm{K}$ in all sampled depths was linear, independently of the K source used (Figure 1). The effect of the different sources on soil $\mathrm{K}$ availability was not statistically significant ( $p>0.05$ for the $F$ test in ANOVA). In plants with no applied K, pineapple cropping from planting to flowering caused soil $\mathrm{K}$ depletion of about $0.5 \mathrm{mmol}_{\mathrm{c}} \mathrm{dm}^{-3}$ at $0-20 \mathrm{~cm}$ depth. The minimum rate of $\mathrm{K}$ application necessary to maintain soil exchangeable $\mathrm{K}$ at the same concentration found prior to pineapple planting $\left(0.7 \mathrm{mmol}_{\mathrm{c}} \mathrm{dm}^{-3}\right)$ was around $290 \mathrm{~kg} \mathrm{ha}^{-1}$ of $\mathrm{K}_{2} \mathrm{O}$ (Figure 1). According to Spironello and Furlani (1997), the rate of $\mathrm{K}$ recommended for pineapple in such soil conditions is $600 \mathrm{~kg} \mathrm{ha}^{-1}$ of $\mathrm{K}_{2} \mathrm{O}$. Comparing to soil $\mathrm{K}$ depletion observed, that rate of $\mathrm{K}$ recommended is more than enough to keep $\mathrm{K}$ availability found prior to pineapple planting.

The changes on soil $\mathrm{K}$ at the $40-60 \mathrm{~cm}$ depth, caused by $\mathrm{K}$ application, indicate that some $\mathrm{K}$ was lost by leaching. As showed in Figure 1, for each $100 \mathrm{~kg} \mathrm{ha}^{-1}$ of $\mathrm{K}_{2} \mathrm{O}$ applied approximately the soil $\mathrm{K}$ at the 40-60 $\mathrm{cm}$ depth increased $0.07 \mathrm{mmol}_{\mathrm{c}} \mathrm{dm}^{-3}$. According to Cunha and Cabral (1999), at this depth there is no significant activity of the pineapple root system, stressing the need to split the rates of $\mathrm{K}$ in order to increase potassium fertilizers efficiency, especially in tropical soils with low cation exchange capacity, such as the one used in the experiment

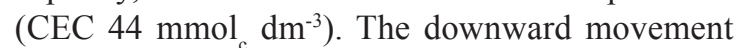
of potassium was the same for all $\mathrm{K}$ sources (Table 1). These results did not agree with those reported by Kleinhenz (1999) who considered that K applied as potassium chloride more vulnerable to losses by leaching than $\mathrm{K}$ as potassium sulphate. This discrepancy might be related with differences in clay content or potassium holding capacity between the soils used in these studies.

The application of $\mathrm{K}_{2} \mathrm{SO}_{4}$ increased significantly soil $\mathrm{S}_{-} \mathrm{SO}_{4}^{-2}$ down to $40-60 \mathrm{~cm}$ soil layer (Table 1 and Figure 2A). The effects were more pronounced in deep layers than in surface one, demonstrating that $\mathrm{S}_{-} \mathrm{SO}_{4}$ was rapidly leached and retained only in the deep layers of the soil profile. Probably it explains why despite the use of SSP as $\mathrm{P}$ source, soil $\mathrm{S}_{-} \mathrm{SO}_{4}$ did not reach the critical level of $10 \mathrm{mg} \mathrm{dm}^{-3}$, for surface soil layer, proposed by Raij et al. (1997).

Potassium fertilization using $\mathrm{KCl}$ and $\mathrm{K}_{2} \mathrm{SO}_{4}+\mathrm{KCl}$ caused a linear increase on soil $\mathrm{Cl}$ content at all sampled depths (Figure 2B). The increase of soil $\mathrm{Cl}$, as consequence of $\mathrm{KCl}$ application, may be of concern, due to pineapple sensitivity to chloride as pointed by Teiwes and Grüneberg (1963), Zehler et al. (1986) and Kleinhenz (1999). Chlorine accumulation in soil is potentially dangerous to intolerant plants and avoiding inputs of this ion through the correct management of fertilizers may be the best choice as demonstrated by Kleinhenz (1999).

\section{Plant nutrition}

Nitrogen concentration in the D-leaf decreased with increasing $\mathrm{K}$ rates (Figure 3), probably due to dilution effect caused by increasing rates of $\mathrm{K}$. Average values of leaf $\mathrm{N}$ were not affected by $\mathrm{K}$ sources (Table 2), and were over critical level (12 $\mathrm{g} \mathrm{kg}^{-1}$ ) proposed by Teixeira et al (2009) for 'Smooth Cayenne' cropped in the state of Sao Paulo (Brazil). The effect of the different sources on K supply to pineapple was not statistically significant ( $>0.05$ for the F test in ANOVA). So, Leaf K increased with the application of $\mathrm{K}$ fertilizers, independently of K source (Figure 3). This result concurred with changes observed on soil $\mathrm{K}$ availability. For leaf $\mathrm{K}$ and soil $\mathrm{K}$ availability, there were no differences between $\mathrm{K}$ sources.

The lower limit considered adequate for leaf $\mathrm{K}$ is $21 \mathrm{~g} \mathrm{~kg}^{-1}$, according to Teixeira et al (2009), was reached with approximately $533 \mathrm{~kg} \mathrm{ha}^{-1}$ of $\mathrm{K}_{2} \mathrm{O}$ (Figure 3). Those results accorded with the recommendations of Spironello and Furlani (1997) for pineapple crop in the State of São Paulo, where is prescribed the rate of $600 \mathrm{~kg} \mathrm{ha}^{-1}$ of $\mathrm{K}_{2} \mathrm{O}$.

Leaf $\mathrm{K}$ content of pineapple plants variation was associated with soil $\mathrm{K}$ availability (Figure 4) and quadratic function was adjusted relating soil and leaf $\mathrm{K}$ concentrations. According to this model, $1.2 \mathrm{mmol}_{\mathrm{c}} \mathrm{dm}^{-3}$ in soil $\mathrm{K}(0-20 \mathrm{~cm})$ was necessary to achieve a desired leaf $\mathrm{K}$ concentration for pineapple plant, around $21 \mathrm{~g} \mathrm{~kg}^{-1}$.

Increasing potassium rates reduced leaf $\mathrm{Ca}$ and $\mathrm{Mg}$ (Table 3). It may be explained by competi- 
tion between ions for transport sites in the plasma membrane of the roots (MARSCHNER, 1997). Lacoeuilhe (1984) reported a strong effect of K accumulation on decreasing leaf contents of $\mathrm{Ca}$ and $\mathrm{Mg}$. Leaf $\mathrm{Ca}$ and $\mathrm{Mg}$ were below the sufficiency limits (8 and $3 \mathrm{~g} \mathrm{~kg}^{-1}$, respectively) proposed by Lacoeuilhe (1984). As the pineapple plants presented normal development, without any symptom of $\mathrm{Ca}$ or $\mathrm{Mg}$ deficiency, it is possible that the sufficiency limits for Ca and Mg suggested by Lacoeuilhe (1984) may be too high for the Smooth Cayenne variety used.

Although single superphosphate with $11 \%$ of $\mathrm{S}$ was applied at planting (450 $\mathrm{kg} \mathrm{ha}^{-1}$ of SSP), the use of $\mathrm{K}_{2} \mathrm{SO}_{4}(X)$ still caused a linear increase $(Y=$ $\left.0.72+0.000282 X ; \mathrm{R}^{2}=0.30 ; \mathrm{p}<0.05\right)$ on leaf sulfur content $(Y)$. The minimum adequate level of leaf $\mathrm{S}$ for pineapple is not clear in the literature: Haag et al. (1963) found that approximately $10 \mathrm{~g} \mathrm{~kg}^{-1}$ of S in the pineapple leaf may be normal and with $6.5 \mathrm{~g} \mathrm{~kg}^{-1}$ of S plants showed deficiency symptoms; differently, Cibes and Samuels (1958) stated that $2.5 \mathrm{~g} \mathrm{~kg}^{-1}$ was a normal value of leaf $\mathrm{S}$ concentration and $1.3 \mathrm{~g} \mathrm{~kg}^{-1}$ was a minimum. Paula et al. (1991) used ammonium sulphate as $\mathrm{N}$ source for pineapple up to $75 \mathrm{~g}\left(\mathrm{NH}_{4}\right)_{2} \mathrm{SO}_{4}$ per plant and found maximum leaf $\mathrm{S}$ content around $1.2 \mathrm{~g} \mathrm{~kg}^{-1}$. In the present experiment, besides the use of SSP, the rate of $700 \mathrm{~kg} \mathrm{ha}^{-1}$ of $\mathrm{K}_{2} \mathrm{O}$ as $\mathrm{K}_{2} \mathrm{SO}_{4}$ increased leaf $\mathrm{S}$ to values not higher than $1.0 \mathrm{~g} \mathrm{~kg}^{-1}$. It is not clear if adequate leaf $\mathrm{S}$ is variety-dependent for pineapple plants but it seems that for the 'Smooth Cayenne' the $1.3 \mathrm{~g} \mathrm{~kg}^{-1}$ suggested as minimum by Cibes and Samuels (1958) may not apply. The low values of leaf $\mathrm{S}$ found may be attributed in some degree to the mobility of $\mathrm{S}_{-} \mathrm{SO}_{4}$ in the soil profile. $\mathrm{S}_{-} \mathrm{SO}_{4}$ is not hold in the surface layers of tropical soils but tend to accumulate in the subsurface layers where the shallow root system of pineapple plants may not efficiently take it up. In the Table 1 is possible to confirm that soil $\mathrm{S}_{-} \mathrm{SO}_{4}$ contents increased with soil depth.
Among micronutrients, only the effects of rates and sources of $\mathrm{K}$ on leaf $\mathrm{Cl}$ content were significant. Other micronutrients leaf contents, as B, $\mathrm{Cu}, \mathrm{Mn}$ and $\mathrm{Zn}$ were not affected neither by rates nor by sources of $\mathrm{K}$ ( $\mathrm{p}>0.05$ for the $\mathrm{F}$ test in ANOVA). The application of $\mathrm{KCl}$ or $\mathrm{K}_{2} \mathrm{SO}_{4}+\mathrm{KCl}$ caused significant increase on leaf $\mathrm{Cl}$ content. At the rate of $700 \mathrm{~kg} \mathrm{ha}^{-1}$ of $\mathrm{K}_{2} \mathrm{O}$ of $\mathrm{KCl}$ or $\mathrm{K}_{2} \mathrm{SO}_{4}+\mathrm{KCl}$, leaf $\mathrm{Cl}$ concentration reached $4.3 \mathrm{~g} \mathrm{~kg}^{-1}$ of $\mathrm{Cl}$ (Figure 5B). Chapman (1973) considered values of leaf $\mathrm{Cl}$ from 1.1 to $4.3 \mathrm{~g} \mathrm{~kg}^{-1}$ as "intermediate range". Samuels and Díaz (1960) applied $270 \mathrm{~kg} \mathrm{ha}^{-1}$ of $\mathrm{K}_{2} \mathrm{O}$ as $\mathrm{KCl}$ or $\mathrm{K}_{2} \mathrm{SO}_{4}$ and found that chloride-fertilized plants contained $6.1 \mathrm{~g} \mathrm{~kg}^{-1}$ of Cl as compared to $3.9 \mathrm{~g} \mathrm{~kg}^{-1}$ of $\mathrm{Cl}$ where potassium sulphate was applied. Py et al. (1984) stated that chlorine from $\mathrm{KCl}$ would not cause problems if its concentration in D-leaf is lower than $17 \mathrm{~g} \mathrm{~kg}^{-1}$ of $\mathrm{Cl}$. The effects of $\mathrm{KCl}$ or $\mathrm{K}_{2} \mathrm{SO}_{4}+\mathrm{KCl}$ on leaf $\mathrm{Cl}$ contents were similar probably because in the combined treatment, $\mathrm{K}_{2} \mathrm{SO}_{4}$ was applied in the first two dressings and $\mathrm{KCl}$ in the last two. So, at leaf sampling, the soil $\mathrm{Cl}$ availability was likely to be the same for both treatments.

Leaf $\mathrm{Cl}$ increased linearly in response to $\mathrm{Cl}$ accumulation in soil (Figure 5A) and as a function of $\mathrm{K}$ fertilization with $\mathrm{KCl}$ or $\mathrm{K}_{2} \mathrm{SO}_{4}+\mathrm{KCl}$ (Figure 5B). Despite the relatively narrow variations in soil $\mathrm{Cl}$ observed for $\mathrm{K}$ sources (Table 1), larger differences were observed in leaf-Cl, demonstrating the pineapple sensitivity to chlorine. It seems that leaf analysis presented better capacity to diagnose $\mathrm{Cl}$ toxicity as compared to soil analysis, although soil sampling was done 8 months after the last split application of $\mathrm{K}$ fertilizers when considerable $\mathrm{Cl}$ leaching may had taken place.

Considering soil $\mathrm{Cl}$ availability and possible problems caused by $\mathrm{Cl}$ for pineapple nutrition, the use of $\mathrm{KCl}$ or $\mathrm{K}_{2} \mathrm{SO}_{4}+\mathrm{KCl}$ as it was applied in this experiment may pose a risk to plants. 
TABLE 1 - Chemical characteristics of soil samples from plots treated with different $\mathrm{K}$ sources. Figures of organic matter content $(\mathrm{OM}), \mathrm{pH}$, available $\mathrm{P}$, exchangeable $\mathrm{K}, \mathrm{Ca}$ and $\mathrm{Mg}$, base saturation $(\mathrm{V})$, sulphur $(\mathrm{S})$ and chlorine $(\mathrm{Cl})$ are average of four rates. Samples collected in November 2004, 17 months after pineapple planting.

\begin{tabular}{|c|c|c|c|c|c|c|c|c|c|}
\hline Source & $\mathrm{OM}$ & $\mathrm{pH}$ & $\mathrm{P}^{(1)}$ & $\mathrm{K}^{(1)}$ & $\mathrm{Ca}^{(1)}$ & $\mathrm{Mg}^{(1)}$ & $\mathrm{V}$ & $\mathrm{S}^{(2)}$ & $\mathrm{Cl}^{(3)}$ \\
\hline & $\mathrm{g} \mathrm{kg}^{-1}$ & & \multicolumn{4}{|c|}{$\begin{array}{c}\mathrm{mg} \mathrm{dm}^{-3} \text {------ } \mathrm{mmol}_{\mathrm{c}} \mathrm{dm}^{-3} \text {-------- } \\
0-20 \mathrm{~cm}\end{array}$} & $\%$ & \multicolumn{2}{|c|}{------ $\mathrm{mg} \mathrm{dm} \mathrm{dm}^{-3}$} \\
\hline $\mathrm{KCl}$ & $20 \mathrm{a}$ & $4.3 \mathrm{a}$ & $5 \mathrm{a}$ & $0.8 \mathrm{a}$ & $7 \mathrm{a}$ & $4 \mathrm{a}$ & $25 \mathrm{a}$ & $2.8 \mathrm{~b}$ & $13.7 \mathrm{a}$ \\
\hline $\mathrm{K}_{2} \mathrm{SO}_{4}$ & $21 \mathrm{a}$ & $4.4 \mathrm{a}$ & $5 \mathrm{a}$ & $0.7 \mathrm{a}$ & $8 \mathrm{a}$ & $4 \mathrm{a}$ & $27 \mathrm{a}$ & $8.7 \mathrm{a}$ & $9.9 \mathrm{~b}$ \\
\hline $\mathrm{K}_{2} \mathrm{SO}_{4}+\mathrm{KCl}$ & $19 \mathrm{a}$ & $4.4 \mathrm{a}$ & $5 \mathrm{a}$ & $0.7 \mathrm{a}$ & $9 \mathrm{a}$ & $5 \mathrm{a}$ & $30 \mathrm{a}$ & $3.6 \mathrm{~b}$ & $14.3 \mathrm{a}$ \\
\hline & \multicolumn{9}{|c|}{$20-40 \mathrm{~cm}$} \\
\hline $\mathrm{KCl}$ & $10 \mathrm{a}$ & $4.2 \mathrm{a}$ & $2 \mathrm{a}$ & $0.4 \mathrm{a}$ & $7 \mathrm{a}$ & $3 \mathrm{a}$ & $24 \mathrm{a}$ & $11.5 \mathrm{~b}$ & $12.7 \mathrm{a}$ \\
\hline $\mathrm{K}_{2} \mathrm{SO}_{4}$ & $9 \mathrm{a}$ & $4.1 \mathrm{a}$ & $2 \mathrm{a}$ & $0.4 \mathrm{a}$ & $6 \mathrm{a}$ & $2 \mathrm{a}$ & $21 \mathrm{a}$ & $20.8 \mathrm{a}$ & $10.1 \mathrm{a}$ \\
\hline $\mathrm{K}_{2} \mathrm{SO}_{4}+\mathrm{KCl}$ & $10 \mathrm{a}$ & $4.1 \mathrm{a}$ & $2 \mathrm{a}$ & $0.4 \mathrm{a}$ & $6 \mathrm{a}$ & $2 \mathrm{a}$ & $21 \mathrm{a}$ & $15.7 \mathrm{~b}$ & $10.2 \mathrm{a}$ \\
\hline & \multicolumn{9}{|c|}{$40-60 \mathrm{~cm}$} \\
\hline $\mathrm{KCl}$ & $8 \mathrm{a}$ & $4.0 \mathrm{a}$ & $1 \mathrm{a}$ & $0.5 \mathrm{a}$ & $5 \mathrm{a}$ & $2 \mathrm{a}$ & $20 \mathrm{a}$ & $13.0 \mathrm{~b}$ & $10.8 \mathrm{a}$ \\
\hline $\mathrm{K}_{2} \mathrm{SO}_{4}$ & $7 \mathrm{a}$ & $4.0 \mathrm{a}$ & $1 \mathrm{a}$ & $0.4 \mathrm{a}$ & $4 \mathrm{a}$ & $2 \mathrm{a}$ & $16 \mathrm{a}$ & $24.0 \mathrm{a}$ & $5.9 \mathrm{~b}$ \\
\hline $\mathrm{K}_{2} \mathrm{SO}_{4}+\mathrm{KCl}$ & $8 \mathrm{a}$ & $4.0 \mathrm{a}$ & $2 \mathrm{a}$ & $0.5 \mathrm{a}$ & $5 \mathrm{a}$ & $2 \mathrm{a}$ & $19 \mathrm{a}$ & $19.8 \mathrm{a}$ & $9.6 \mathrm{ab}$ \\
\hline
\end{tabular}

${ }^{(1)}$ Extracted with ion exchange resin; ${ }^{(2)} \mathrm{S}_{-} \mathrm{SO}_{4}$ extracted with $\mathrm{Ca}\left(\mathrm{H}_{2} \mathrm{PO}_{4}\right)_{2}$; ${ }^{(3)}$ extracted with water.

For the same soil layer and within columns, values not followed by the same letter indicate that sources are significantly different according to Tukey's test $(\mathrm{p}<0.05)$.

TABLE 2 - Means of N, K, P, Ca, Mg, S, and Cl contents in D-leaf for potassium sources. Sampling in September 2004, 15 months after pineapple was planted.

\begin{tabular}{cccccccc}
\hline Source of K & $\mathrm{N}$ & $\mathrm{K}$ & $\mathrm{P}$ & $\mathrm{Ca}$ & $\mathrm{Mg}$ & $\mathrm{S}$ & $\mathrm{Cl}$ \\
\hline & -------------------------- & $\mathrm{g} \mathrm{kg}^{-1}-----------------------$ & $\mathrm{mg} \mathrm{kg}^{-1}$ \\
$\mathrm{KCl}$ & $14.9 \mathrm{a}$ & $15.9 \mathrm{a}$ & $0.8 \mathrm{a}$ & $1.6 \mathrm{a}$ & $1.3 \mathrm{a}$ & $0.7 \mathrm{~b}$ & $2447 \mathrm{a}$ \\
$\mathrm{K}_{2} \mathrm{SO}_{4}$ & $15.5 \mathrm{a}$ & $14.9 \mathrm{a}$ & $0.8 \mathrm{a}$ & $1.6 \mathrm{a}$ & $1.4 \mathrm{a}$ & $0.8 \mathrm{a}$ & $538 \mathrm{~b}$ \\
$\mathrm{~K}_{2} \mathrm{SO}_{4}+\mathrm{KCl}$ & $14.6 \mathrm{a}$ & $15.9 \mathrm{a}$ & $0.8 \mathrm{a}$ & $1.6 \mathrm{a}$ & $1.3 \mathrm{a}$ & $0.7 \mathrm{~b}$ & $2284 \mathrm{a}$ \\
\hline
\end{tabular}

Within columns, values not followed by the same letter indicate that sources are significantly different according to Tukey’s test ( $\mathrm{p}<0.05$ ).

TABLE 3 - Effect of $\mathrm{K}$ rates (X) and sources on $\mathrm{Ca}$, and Mg D-leaf contents (Y) of pineapple. Sampling in September 2004, 15 months after pineapple was planted.

\begin{tabular}{cccc}
\hline D-leaf content $(\mathrm{Y})$ & Function & $\mathrm{R}^{2}$ & $\mathrm{p}$ value \\
\hline $\mathrm{Ca}\left(\mathrm{g} \mathrm{kg}^{-1}\right)$ & $\mathrm{Y}=1.793-0.0006 \mathrm{X}$ & 0.30 & $<0.001$ \\
$\mathrm{Mg}\left(\mathrm{g} \mathrm{kg}^{-1}\right)$ & $\mathrm{Y}=1.502-0.0006 \mathrm{X}$ & 0.48 & $<0.001$ \\
\hline
\end{tabular}




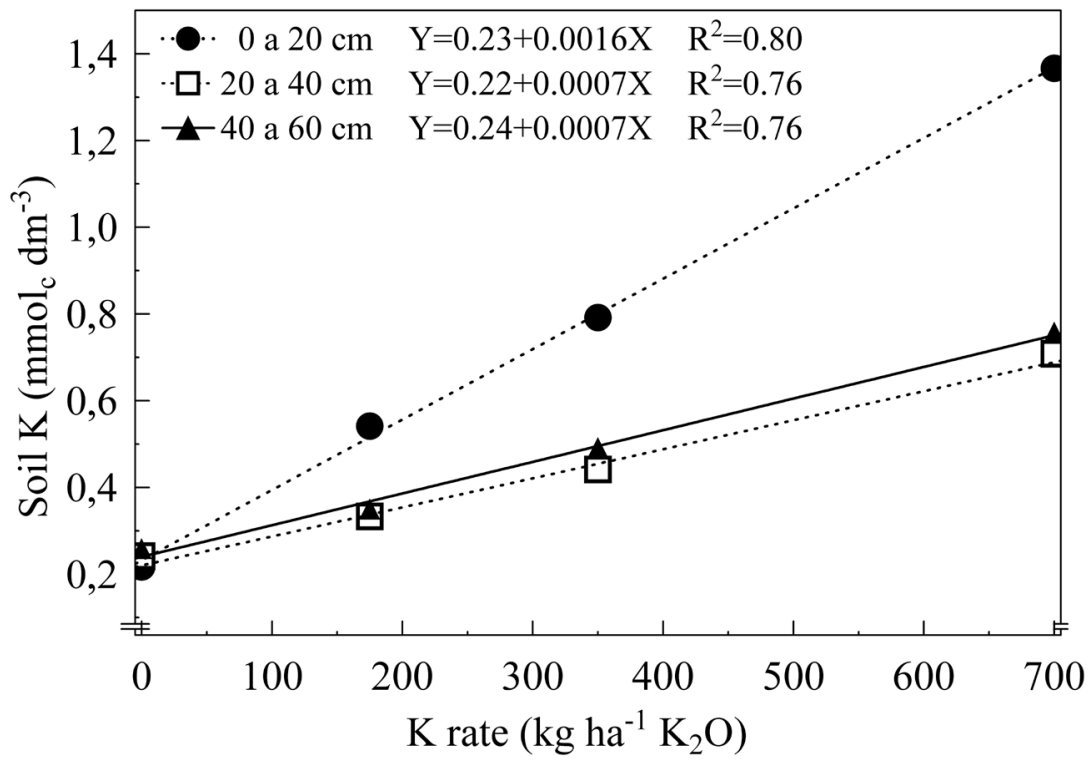

FIGURE 1 - Soil exchangeable $\mathrm{K}$ as a function of $\mathrm{K}$ fertilization. Effects of $\mathrm{KCl}, \mathrm{K}_{2} \mathrm{SO}_{4}+\mathrm{KCl}$ and $\mathrm{K}_{2} \mathrm{SO}_{4}$ applications on K contents of three soil layers. Soil samples collected in November 2004, 17 months after pineapple planting.

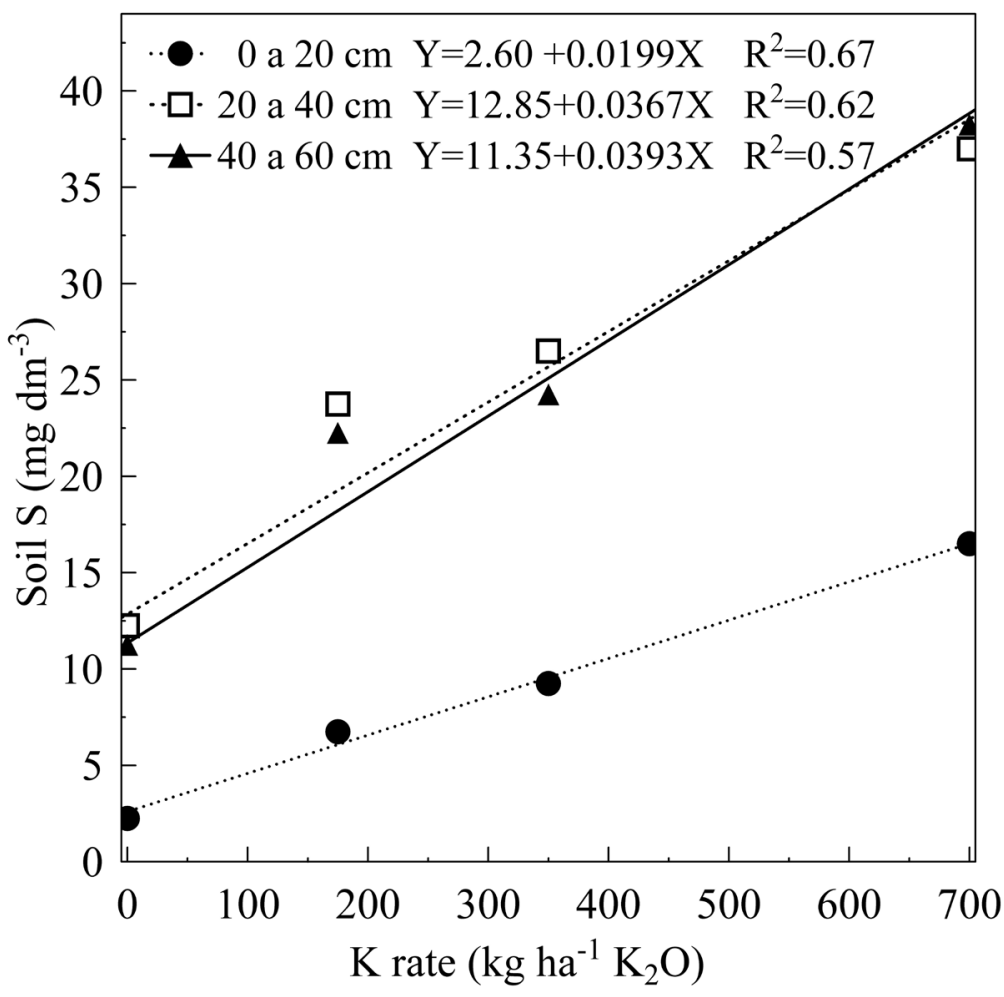

A 


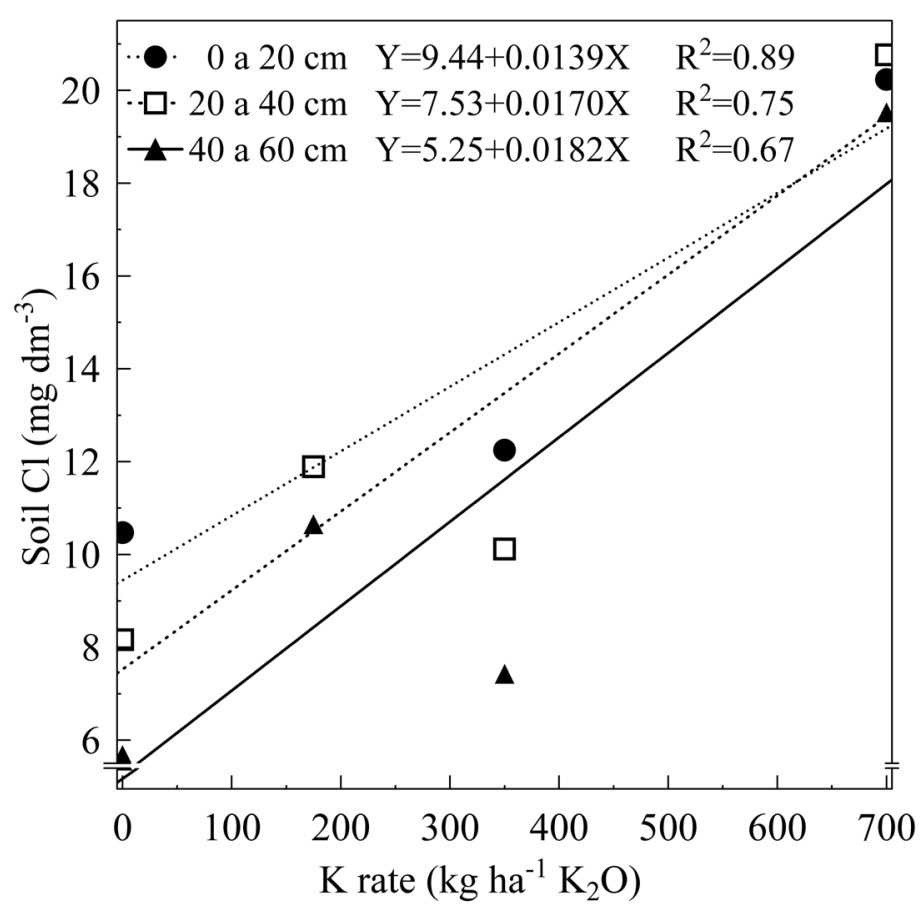

$\mathrm{B}$

FIGURE 2 - Soil $\mathrm{S}$ contents (A) as a function of $\mathrm{K}$ fertilization with $\mathrm{K}_{2} \mathrm{SO}_{4}$ and soil chloride (B) contents as a function of $\mathrm{K}$ fertilization with $\mathrm{KCl}$ or $\mathrm{K}_{2} \mathrm{SO}_{4}+\mathrm{KCl}$ of three soil layers. Soil samples collected in November 2004, 17 months after pineapple planting.

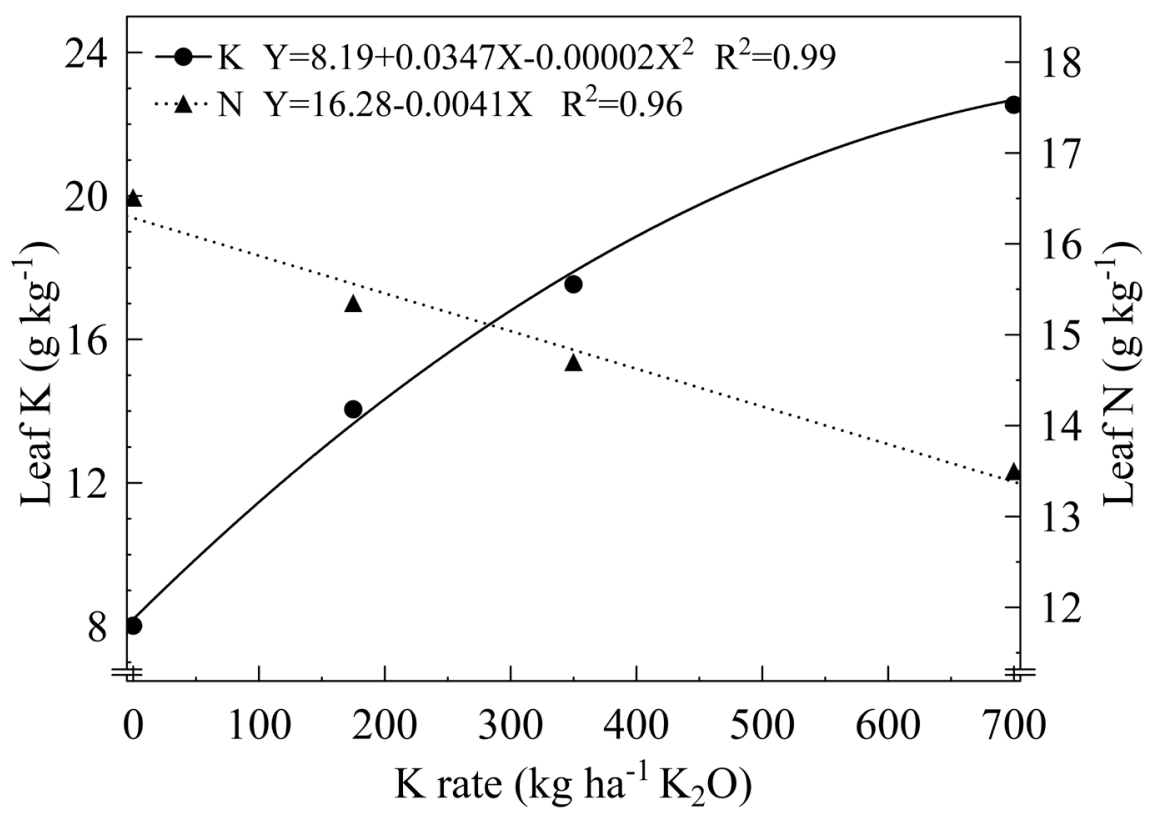

FIGURE 3- Potassium and nitrogen contents of D-leat of pineapple plants as influenced by rates of potassium independently of K source. Sampling in September 2004. 


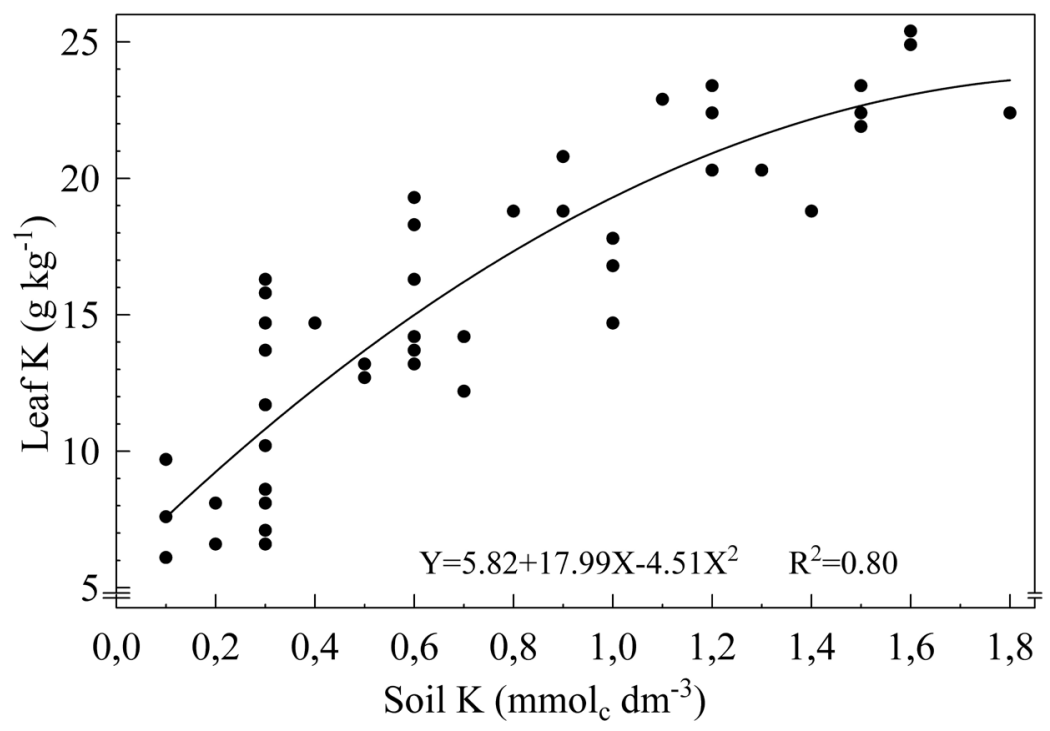

FIGURE 4 - Potassium content of D-leaf of pineapple plants as a function of exchangeable soil K. Sampling in September 2004.

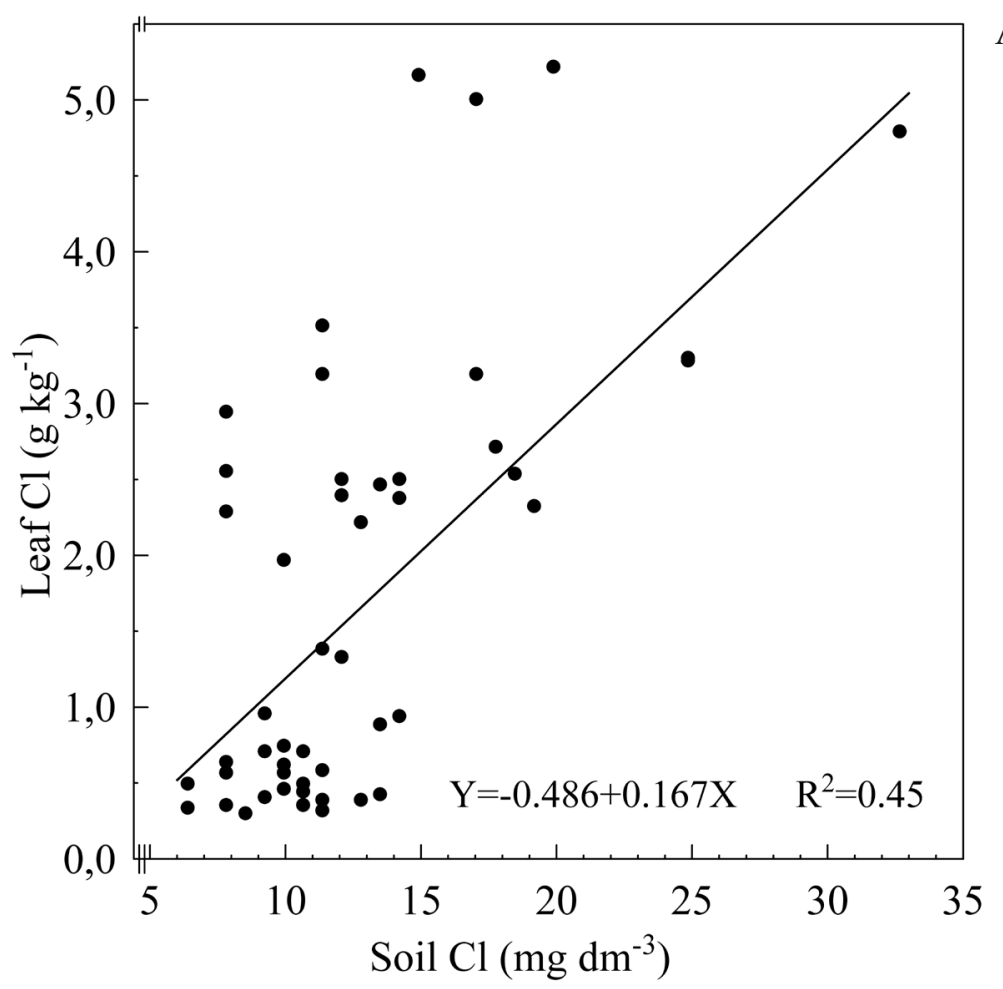




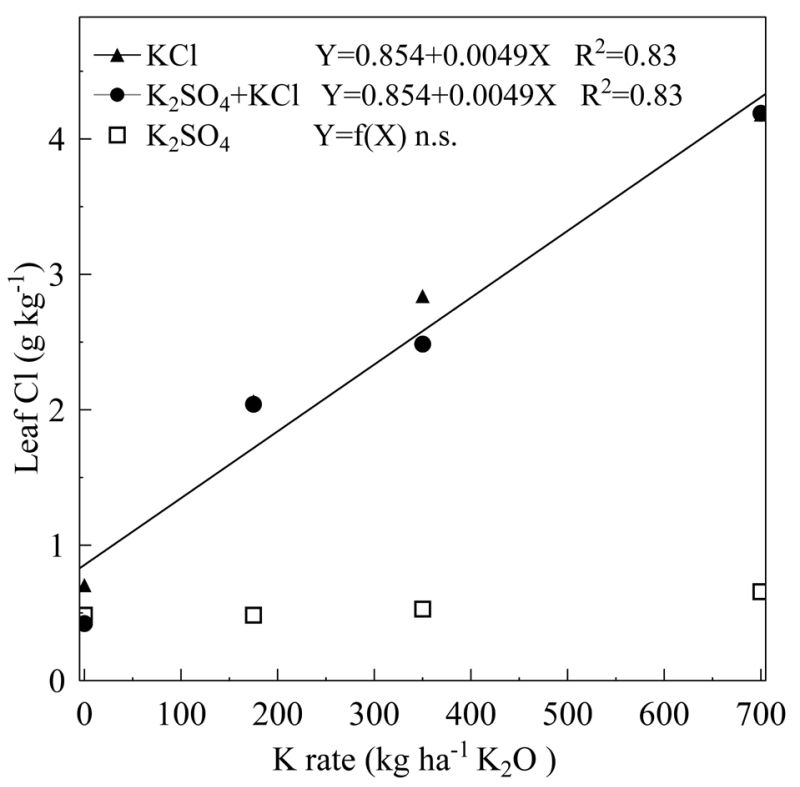

FIGURE 5 - Chlorine content of D-leaf of pineapple plants as a function of soil $\mathrm{Cl}(\mathrm{A})$ and $\mathrm{Cl}$ content of D-leaf of pineapple plants as a function of sources and rates of $\mathrm{K}$ fertilizer (B). Sampling in September 2004.

\section{CONCLUSIONS}

1-The use of $\mathrm{KCl}$ or $\mathrm{K}_{2} \mathrm{SO}_{4}+\mathrm{KCl}$ as a source of $\mathrm{K}$ to pineapple increased soil $\mathrm{Cl}$ availability and $\mathrm{Cl}$ contents of plant leaves in comparison to $\mathrm{K}_{2} \mathrm{SO}_{4}$ application.

2-Pineapple K uptake was influenced by $\mathrm{K}$ rates and by soil $\mathrm{K}$ availability, regardless of $\mathrm{K}$ sources.

\section{ACKNOWLEDGEMENTS}

The authors are grateful to Milton and Armando Yoshiura, pineapple growers, for their support for field activities and to Sulphate of Potash Information Board (SOPIB) and to Fundação de Apoio à Pesquisa Agrícola (FUNDAG), for financial support.

\section{REFERENCES}

BATAGLIA, O.C.; FURLANI, A.M.C.; TEIXEIRA, J.P.F.; FURLANI, P.R.; GALLO, J.R. Métodos de análise química de plantas. Campinas: IAC, 1983. 48p. (Boletim Técnico, 78)

CHAPMAN, H.D. Diagnostic criteria for plants and soils. Riverside: Deptartment of Soils and Plant Nutrition, University of California, 1973. 793p.
CIBES, H., SAMUELS, G. Mineral-deficiency symptoms displayed by Red Spanish pineapple plants grown under controlled conditions. Rio Piedras: University of Puerto Rico, 1958. 32p. (Technical Paper, 25)

CUNHA, G.A.P.; CABRAL, J.R.S. Taxonomia, espécies, cultivares e morfologia. In: CUNHA, G.A.P.; CABRAL, J.R.S.; SOUZA, L.F.S. (Ed.). $\mathbf{O}$ abacaxizeiro: cultivo, agroindústria e economia. Brasília: EMBRAPA, 1999. p.17-51.

HAAG, H.P., ARZOLLA, S., MELLO, F.A.F., BRASIL SOBRINHO, M.O.C., OLIVEIRA, E.R., MALAVOLTA, E. Estudos sôbre a alimentação mineral do abacaxi (Ananas ativus) Sch. Anais da Escola Superior de Agricultura "Luiz de Queiroz", Piracicaba, v.20, p.33-40, 1963

HEPTON, A. Cultural system. In: BARTHOLOMEW, D.P.; PAULL, R.E.; ROHRBACH, K.G. (Ed.). Pineapple: botany, production and uses. Wallingford: CABI Publishing, 2003. p.109-142.

KLEINHENZ, V. Sulfur and chloride in the soilplant system. Kassel: K+S Group, 1999. 99p. 
LACOEUILHE, J.J. Ananas. In: MARTIN-PRÉVEL, P.; GAGNARD, J.; GAUTIER, P. (Ed.) L'analyse végétale dans le contrôle de l'alimentation des plantes tempérées et tropicales. Paris: Tec\&Doc, 1984. p.675-694.

LACOEUILHE, J.J. La fumure N-K de l'ananas em Côte d'Ivoire. Fruits, Paris, v.33, n.5, p.341-348, 1978.

MARSCHNER, H. Mineral nutrition of higher plants. $2^{\text {nd }}$ ed. San Diego: Academic Press, 1997. 889p.

PY, C.; LACOEUILHE, J.J.; TEISSON, C. L'Ananas. Paris: G.P. Maisonneuve et Larose et ACCT, 1984. 562p.

PAULA, M.B.; CARVALHO, V.D.; NOGUEIRA, F.D.; SOUZA, L.F. Efeito da calagem, potássio e nitrogênio na produção e qualidade do fruto do abacaxizeiro. Pesquisa Agropecuária Brasileira, Brasília, v.26, n.9, p.1337-1343, 1991.

RAIJ, B. van; ALCARDE, J.C.; CANTARELLA, H.; QUAGGIO, J.A. (Ed.). Análise química para avaliação da fertilidade de solos tropicais. Campinas: IAC, 2001. 285p.

RAIJ, B. van; CANTARELLA, H.; QUAGGIO, J.A.; FURLANI, A.M.C. Interpretação de resultados de análise de solo. In: RAIJ, B. van; CANTARELLA, H.; QUAGGIO, J.A.; FURLANI, A.M.C. (Ed.). Recomendações de adubação e calagem para o Estado de São Paulo. 2.ed. Campinas: IAC, 1997. p.8-13. (Boletim Técnico, 100)

RAYMENT, G.E.; HIGGINSON, F.R. Soluble chloride. In: RAYMENT, G.E.; HIGGINSON, F.R. Australian laboratory handbook of soil and water chemical methods. Melbourne: Inkata Press, 1992. p.24-27.
SAMUELS, G.; DÍAZ, H.G. Effects of potassium chloride and sulfate on pineapple yields and quality. The Journal of Agriculture of the University of Puerto Rico, Rio Piedras, v.44, n.1, p.16-20, 1960.

SPIRONELLO, A.; FURLANI, P.R. Abacaxi. In: RAIJ, B. van; CANTARELLA, H.; QUAGGIO, J.A.; FURLANI, A.M.C. (Ed.). Recomendações de adubação e calagem para o Estado de São Paulo. 2.ed. Campinas: IAC, 1997. p.128. (Boletim Técnico, 100)

SPIRONELLO, A.; QUAGGIO, J.A.; TEIXEIRA, L.A.J.; FURLANI,P.R.; SIGRIST, J.M.M. Pineapple yield and fruit quality effected by NPK fertilization in a tropical soil. Revista Brasileira de Fruticultura, Jaboticabal, v.26, n.1, p.155-159, 2004.

TEIWES, G.; GRÜNEBERG, F. Conocimientos y experiencias en la fertilización de la piña. Boletín Verde, Hannover, v.3, p.1-67, 1963.

TEIXEIRA，L.A.J.; SPIRONELLO，A.; FURLANI,P.R.; SIGRIST, J.M.M. Parcelamento da adubação NPK em abacaxizeiro. Revista Brasileira de Fruticultura, Jaboticabal, v.24, n.1, p.219-224, 2002.

TEIXEIRA, L.A.J.; QUAGGIO, J.A.; ZAMBROSI, F.C.B. Preliminary Dris norms for 'Smooth Cayenne' pineapple and derivation of critical levels of leaf nutrient concentrations. Acta Horticulturae, Leuven, n.822, p.131-138, 2009.

ZEHLER, E.; KREIPE, H.; GETHING, P.A. Sulfato de potássio e cloreto de potássio: sua influência na produção e qualidade das plantas cultivadas. Campinas: Fundação Cargill, 1986. 111p. 